\title{
A PAISAGEM \\ SÓCIO-LINGUÍSTICA: \\ A POLÍTICA, \\ A DIVERSIDADE \\ E A MIGRAÇÃO \\ NO ESPAÇO \\ PÚBLICO
}

\section{EL PAISAJE SOCIOLINGÜÍSTICO: LA POLÍTICA, LA DIVERSIDAD Y LA MIGRACIÓN EN EL ESPACIO PÚBLICO}

\author{
THE SOCIOLINGUISTIC LANDSCAPE: POLITICS, DIVERSITY AND MIGRATION IN THE \\ PUBLIC SPACE
}

Karolina Bielenin-Lenczowska*

Universidade de Varsóvia | Universidade Federal de Santa Catarina

\begin{abstract}
RESUMO: No presente artigo, discute-se o conceito acerca da paisagem linguística. Combinando os métodos etnográficos com os linguísticos, visa-se fornecer uma imagem mais completa de dois lugares diversos: a da cidade suburbana de Varsóvia e a de uma colônia habitada por descendentes de migrantes poloneses no Brasil. Argumenta-se que a análise dos aspectos materiais do espaço público observados nestas regiões, bem como os provenientes dos encontros etnográficos, nos permite entender melhor a visibilidade e a invisibilidade dos vários grupos em questão. Por outro lado, nos permite também observar diversas práticas de comunicação formais e informais e reconhecer o espaço limitado para expressar a diversidade linguística e étnica, acessível para aqueles que habitam o município. Além disso, acredita-se que a análise da comunicação escrita é insuficiente, porque alguns grupos estão presentes mais auditivamente do que visualmente.
\end{abstract}

PALAVRAS-CHAVE: Diáspora. Migração. Paisagem. Etnografia. Espaço público.

RESUMEN: En este artículo se discute el concepto de paisaje lingüístico. Combinando métodos etnográficos y lingüísticos, el objetivo es proporcionar una imagen más completa de dos lugares diferentes: la de la ciudad suburbana de Varsovia y la de una colonia habitada por descendientes de inmigrantes polacos en Brasil. Se argumenta que el análisis de los aspectos materiales del

\footnotetext{
*Karolina Bielenin-Lenczowska - antropóloga social e linguista, professora do Instituto de Etnologia e Antropologia Cultural da Universidade de Varsóvia e professora visitante no Departamento de Linguística na Universidade Federal de Santa Catarina. Ela realiza pesquisas etnográficas e sociolinguísticas sobre migração e diáspora.E-mail: k.bielenin@gmail.com
} 
espacio público observados en estas regiones, así como los que surgen de los encuentros etnográficos, permite comprender mejor la visibilidad e invisibilidad de los distintos grupos en cuestión. Por otro lado, también nos permite observar diferentes prácticas de comunicación formales e informales y reconocer el espacio limitado para expresar la diversidad lingüística y étnica, accesible a quienes habitan el municipio. Además, se cree que el análisis de la comunicación escrita es insuficiente, porque algunos grupos están presentes más de forma audible que visual.

PALABRAS CLAVE: Diáspora. Migración. Paisaje. Etnografía. Espacio público.

ABSTRACT: In this paper, I discuss the concept of Linguistic Landscape. Combining ethnographic and linguistic methods, I try to provide a more complete picture of two diverse neighbourhood: in a suburbian town of Warsaw, and in a village inhabited by descendents of Polish migrants in Brazil. I argue that the analysis of both the material dimensions of the public space observed while walking through the neighbourhood and the ethnographic encounters, enables us to understand the visibility and invisibility of the various groups better. It also allows us to observe formal and informal communication practices and recognize the limited space for expressing one's linguistic and ethnic diversity, which is available to those inhabiting the municipality. Moreover, I argue that the analysis of written communication is insufficient, because some groups are present more audially than visually.

KEYWORDS: Diaspora. Migration. Landscape. Ethnography. Public space.

\section{INTRODUÇÃO}

Os espaços públicos constituem tanto os espaços geográficos como os instrumentos de poder. Pierre Bourdieu, em Language and Symbolic Power, escreve que a língua oficial de um estado está intimamente ligada às suas instituições. Esta língua não só é exigida por ocasião de eventos oficiais e em todos os espaços públicos (escolas, administração pública, instituições políticas etc.), mas também, sendo uma língua oficialmente normalizada e unificada, domina todas as outras formas e práticas linguísticas presentes em determinado lugar (BOURDIEU, 1991, p. 45-46).

Um dos conceitos que permitem a análise de práticas linguísticas no espaço público e indexam as diferenças e as hierarquias sociais é o conceito da "paisagem linguística". Este conceito já está bem enraizado no campo da sociolinguística e, apesar de muitas observações críticas, ainda constitui uma fonte inspiradora de pesquisa, conforme mencionado por Woldemariam e Lanza (2015, p. 172): "[... como várias formas de linguagem e discurso são exibidas em espaços públicos indexam diversas ideologias e identidades, além de lutas pelo poder e contestações”.. Numa investigação acadêmica quanto à vitalidade etno-linguística e à sinalização, realizada no Canadá, os pesquisadores canadenses Rodriguez Landry e Richard Bourhis, pela primeira vez, definiram o conceito da paisagem linguística e comentaram que "[...] a linguagem de sinais de trânsito público, os cartazes publicitários, os nomes de ruas, os nomes de lugares, as marcas registradas e os sinais públicos nos edifícios, todos estes elementos, em conjunto, formam uma paisagem linguística de um determinado território, região ou cidade" (LANDRY; BOURHIS, 1997, p. 25, tradução minha) $)^{1}$.

Em geral, a principal tarefa da pesquisa relativa à paisagem linguística é refletir a situação sociolinguística da área. Para tal efeito, pretende-se descrever a diversidade linguística e cultural, refletir o grau de uso de determinadas línguas e ligar estes fenômenos à política da linguagem e a um senso de identidade linguística.

Inicialmente, a pesquisa de campo quanto às paisagens linguísticas foi conduzida por sociolinguistas, sobretudo nas grandes cidades, e focou-se na análise qualitativa e quantitativa da presença da(s) língua(s) escrita(s) no espaço público. Os elementos que foram analisados são os sinais que se enquadram nos conceitos "de cima para baixo" e "de baixo para cima" (top-down e bottom$u p$, respectivamente). Os primeiros deles pertencem à política no que toca ao idioma local e que estão com mais frequência

${ }^{1}$ No original: "The language of public road signs, advertising billboards, street names, place names, commercial shop signs, and public signs on government buildings combines to form the linguistic landscape of a given territory, region, or urban agglomeration”. 
relacionados ao multilinguíssimo da cidade ou da região, ou, inclusive, ao desenvolvimento do turismo (ou seja, nomes de ruas, sinais de trânsito). As placas bottom-up são colocadas pelos próprios moradores locais ou por pessoas que administram os negócios a nível local, e estas placas incluem nomes de lojas e de restaurantes, os grafites e diversos anúncios (BEN-RAFAEL; SHOHAMY; AMARA; TRUMPER-HECHT, 2006). A pesquisa realizada até agora tem se preocupado principalmente com a identidade e a transformação do espaço da cidade, além de prestar mais atenção às tensões e conflitos entre a língua dominante e as línguas minoritárias.

Na presente pesquisa, pretendemos analisar a paisagem linguística de pequenos municípios e aplicar as teorias desenvolvidas pelos estudiosos que combinam os métodos etnográficos com a linguística, juntando assim a "segunda onda" de pesquisa sobre paisagem linguística (BLOMMAERT, 2016). Portanto, optamos por usar o termo "sócio-linguístico" em vez de apenas "linguístico". Convém assinalar que, no presente artigo, liga-se também o conceito de paisagem linguística ao conceito de paisagem cultural, definido na Antropologia Social por sua relação com a vida social e cultural das pessoas que moram em um determinado local; suas memórias, narrativas e conceituações locais do espaço (cf. HIRSH; O'HANLON, 1995). Ao mesmo tempo, consideramos a pesquisa sobre uma paisagem sonora bastante inspiradora (cf. SAMUELS et al., 2010). Estamos convencidos de que a investigação acerca das práticas linguísticas utilizadas no espaço público deve concentrar-se não apenas na linguagem escrita, mas também na comunicação falada.

Na presente análise, adotamos um conceito de “análise etnográfica da paisagem linguística”, cunhada por Jan Blommaert e Ico Maly (2014), os quais definem os espaços públicos como áreas sociais impermanentes e como instrumentos de poder. Também consideramos de grande relevância a abordagem da Jackie Jia Lou que analisa as relações e as práticas sociais quanto ao uso de diferentes linguagens e dialetos (JIA LOU, 2016). Os estudos sobre o multilinguismo nos espaços urbanos também fornecem uma nova perspectiva, na qual são mapeadas as áreas de atividades dos migrantes, incluindo as práticas linguísticas deles (GOGOLIN; SIEMUND; SCHULZ; DAVYDOVA, 2013). Portanto, o objetivo da pesquisa em questão é descobrir não apenas a presença e a disseminação de diversos idiomas e dialetos, mas também as possíveis ligações com as comunidades e os bairros determinados, as práticas organizacionais de diferentes grupos e as relações entre eles (BLOMMAERT; MALY, 2014, p. 3 e 22). Consideramos relevante entender "[...] o relacionamento entre as práticas urbanas multilíngues e instituições relativamente monolíngues, mesmo nas áreas urbanas em que as altas porcentagens da população são influenciadas pelas culturas diferentes" (BRECKNER; PEUKERT; PINTO, 2013, p. 213, tradução minha) $)^{2}$.

À vista disso, convém explicar agora o conceito de paisagem linguística, discutindo os dois exemplos: o caso da Polônia, na pequena cidade de Raszyn, localizada perto de Varsóvia; e o caso relativo ao sul do Brasil, no município de Mallet. Embora aparentemente não seja possível comparar ambos os exemplos, visto que no caso da cidade polonesa de Raszyn abordaremos a questão dos imigrantes contemporâneos da Índia ou da Ucrânia, enquanto no caso do Brasil a questão está ligada à terceira ou quarta geração de migrantes das terras polonesas, acreditamos que os dois exemplos nos permitem discutir como podemos estudar a paisagem sociolinguística e quão útil pode ser este conceito tanto para a linguística quanto para a antropologia.

Os dados que apresentaremos ao longo desta investigação provêm da combinação de vários métodos, como as particularidades da antropologia cultural e as de caráter mais linguístico. Utilizamos os métodos etnográficos clássicos, ou seja, as entrevistas formais e informais (em polonês, português e inglês), a observação participante acompanhada pelas notas de campo, bem como a análise de materiais visuais. É também de grande relevância acompanhar os interlocutores e observar as atividades deles com o objetivo de avaliar a forma como eles percorrem e reconhecem os diferentes elementos do espaço (SZABÓ; TROYER, 2017), "[...] ver os sinais como índices de relações sociais, interesses e práticas" (BLOMMAERT; MALY, 2014, p. 4, tradução minha) ${ }^{3}$, bem como perceber "[...] como as várias formas de linguagem e discurso exibidas nos espaços públicos indexam diversas ideologias e identidades" (WOLDEMARIAM; LANZA, 2015, p. 172, tradução minha). ${ }^{4}$ A pesquisa realizada em Raszyn, durante o período de 2017-2018,

\footnotetext{
${ }^{2}$ No original: "[...] the relationship between multilingual urban practices and more or less monolingual institutions even in those urban areas where high percentages of the population are influenced by different cultures."

${ }^{3}$ No original: "[...] see signs as indices of social relationships, interests and practices."

${ }^{4}$ No original: "How various forms of language and discourse displayed in public spaces index diverse ideologies and identities."
} 
fez parte do projeto "Domesticar o espaço entre os migrantes e os refugiados. A antropologia da mobilidade em torno de Varsóvia”, da Universidade de Varsóvia. Os integrantes do projeto, as organizadoras Karolina Bielenin-Lenczowska e Helena Patzer e um grupo de onze estudantes, passaram cerca de cinco semanas em Raszyn e seus arredores. Neste artigo, usamos os dados retirados de oito entrevistas e conversas que foram conduzidas em polonês e inglês, além de fotografias tiradas por Helena Patzer. Todas as entrevistas foram realizadas no local de trabalho do entrevistado, sendo elas gravadas e, em seguida, transcritas, ou propriamente anotadas. Além disso, foram conduzidas diversas conversas informais e também foram feitas as observações no pátio do templo sikh. Convém acrescentar que também foram regularmente anotadas todas as observações e conversas no diário de campo (cerca de vinte páginas de manuscrito). O diário mantém-se em polonês.

A pesquisa em Rio Claro e os seus arredores, por sua vez, está sendo realizada a partir de 2015 até este momento ${ }^{5}$. No campo, Karolina Bielenin-Lenczkowska passou cerca de três meses conversando com as pessoas, participando de diversas festividades, serviços, andando pelos campos com os proprietários das terras e acompanhando as suas atividades diárias, além de participar das refeições junto com os moradores. Durante a estadia no campo, havia uma possibilidade de morar na casa dos descendentes poloneses. Dessa forma, foi possível realizar mais de trinta entrevistas, tanto estruturadas como não estruturadas, tanto com as mulheres, quanto com os homens. A faixa etária dos interlocutores compreende as pessoas nascidas entre as décadas de 1930 e 1990. Para este fim, foi usado o método de entrevistas biográficas, em particular aquelas com os elementos de biografias linguísticas (NEKVAPIL, 2003; GOCZYŁA FERREIRA, 2019). A maioria das conversas foi realizada nas casas dos interlocutores. Além das entrevistas, foram observadas as suas atividades cotidianas, por exemplo, o trabalho na roça e a preparação de refeições. Às vezes, havia uma oportunidade de ajudar-lhes, sobretudo na cozinha. Como parte dessas observações, tudo foi anotado em um diário, tendo como base as notas de campo (cerca de quarenta páginas de um manuscrito; em polonês). Além disso, foi criada uma documentação fotográfica.

\section{CASO 1: RASZYN, POLÔNIA}

Acreditamos que a Polônia continua sendo um país de emigração mais do que um país de imigração. Porém, há algum tempo, sobretudo a partir da entrada da Polônia na União Europeia, nota-se cada vez mais imigrantes. O grupo mais numeroso é constituído pelos ucranianos oriundos tanto da parte ocidental da Ucrânia, quanto da parte leste deste país, em particular depois da anexação da Crimeia e do conflito em Donbas (2014-2015) (KINDLER, 2011; JÓŹWIAK, PIECHOWSKA, 2017). Os habitantes da parte oriental da Ucrânia são falantes de língua russa, enquanto os do oeste falam ucraniano. Os dois idiomas parecem semelhantes com o polonês, embora o ucraniano seja mais parecido, razão pela qual estes migrantes aprendem o polonês muito rápido. Acontece que, pelo sotaque diferente, é possível notar que eles não são da Polônia - sendo o motivo da exclusão do idioma - mas logo após a chegada, eles conseguem arranjar um emprego. A maioria das mulheres trabalha no setor de serviços domésticos (como faxineiras ou babás) ou em lojas e restaurantes. Os homens, por sua vez, geralmente trabalham no canteiro de obras, muitos deles também são motoristas da UBER. Nas pequenas cidades, muitos ucranianos e muitas ucranianas trabalham no setor agrícola.

O estudo de caso apresentado neste artigo foi realizado em um município suburbano de Varsóvia, chamado Raszyn, habitado por um número considerável e crescente de migrantes oriundos de vários países: Índia, Turquia, Ucrânia, Vietnã e outros. Tal como muitas outras áreas suburbanas, é uma zona semirrural, com um número significativo de pessoas envolvidas no setor agrícola. Porém, por outro lado, é o lar para várias pequenas empresas. O Raszyn é um caso singular na Polônia, pois, desde os anos de 1990, continua atraindo uma população migrante, em parte devido ao fato de estar próximo ao maior centro comercial asiático da Polônia, Wólka Kosowska (PIŁAT, 2013). Atualmente, no município, se nota um aumento do número de migrantes que vivem nesta região, principalmente aqueles provenientes da Índia e de outros países do sul da Ásia, mas também da Ucrânia. No entanto, a situação é muito dinâmica e está sujeita a alterações resultantes da mudança da política de migração, da mudança do mercado de trabalho e das possibilidades que surgem para os migrantes em outros lugares.

\footnotetext{
${ }^{5}$ Pesquisa em 2015 e 2016 frealizada graças à bolsa de pós-doutorado "Fellow Mundus" implementada na Universidade Federal de Santa Catarina, no Departamento da Antropologia.
} 
Embora para muitos dos novos moradores o subúrbio seja principalmente um local apenas para dormir, pode-se observar que os migrantes alteram-no e reorganizam-no de várias maneiras diferentes, deixando assim os traços de sua presença no espaço público. Entre várias iniciativas tomadas pelos migrantes, se nota uma grande quantidade de pequenos estabelecimentos, como restaurantes étnicos e lojas de comida oriental, os quais estão sendo instalados naquela área. Os filhos dos migrantes frequentam as escolas locais (infantis e fundamentais), constantemente desafiando as instituições em questão e fazendo com que estas tenham que repensar as suas práticas cotidianas. Os elementos que, de uma maneira significativa, contribuem para esta diversidade étnica e linguística, são os vários lugares de culto que foram construídos para atender as necessidades das comunidades migrantes na área. Entre esses locais, destaca-se o Sikh Gurdwara (o maior templo em toda a Europa Central e Oriental) que está presente no município desde 2009, localizado ao lado de uma casa de oração muçulmana; enquanto os dois templos budistas vietnamitas, uma sala de oração muçulmana e um templo hindu e um hare-krishna atuam nas aldeias vizinhas.

Em geral, as instituições e o setor de serviço na Polônia ainda não se adaptaram linguisticamente à sociedade que está cada vez mais diversa. A Polônia é oficialmente um país monolíngue e o domínio linguístico (BOURDIEU, 1991) do idioma polonês está presente em todas as esferas da vida social (cf. GOGOLIN; SIEMUND; SCHULZ; DAVYDOVA, 2013). Além disso, tal como nos países europeus mais etnicamente diversos, por exemplo a Alemanha, na Polônia, uma das medidas de integração de imigrantes é o conhecimento da língua do Estado e, conforme mencionado por Breckner, Peukert e Pinto (2013, p. 213, tradução minha): “[...] as manifestações escritas e orais do potencial multilíngue dos imigrantes [...] não são levadas em consideração ou são intencionalmente ignoradas" ${ }^{\text {. }}$ Raszyn não é uma exceção: em todas as secretarias do estado apenas se fala polonês e se exige que os migrantes compareçam com seus próprios tradutores, sendo estes, às vezes, enviados pelas ONGs, no caso de não entenderem o polonês. O mesmo acontece também nos serviços públicos, como nos da saúde e da educação, onde somente se usa polonês, e que têm pouca flexibilidade linguística. Conforme foi observado, a língua vietnamita e inglesa são as duas línguas mais usadas (faladas), embora os habitantes do município também sejam indianos, turcos, nepaleses, ucranianos, bielorrussos, russos e de outras origens. Estes dois idiomas servem para qualquer informação que não seja divulgada em polonês: o vietnamita para a comunidade local de migrantes da primeira, segunda e terceira geração do Vietnã; e o inglês para todos os demais.

Via de regra, o município não oferece sinais de top-down em outro idioma que não seja o polonês. Convém assinalar que não se trata de uma comunidade bilíngue ou multilíngue, como aquelas da fronteira entre a Polônia e Bielorrússia ou Polônia e Alemanha. No entanto, a visibilidade de algumas comunidades, especialmente daquelas já estabelecidas, é bastante alta. Um desses grupos bem mais visíveis e reconhecidos é a comunidade vietnamita, sendo considerada o maior grupo de migrantes da Ásia na Europa Central e Oriental (SZYMAŃSKA-MATUSIEWICZ, 2016). Outro grupo visível neste município são os turcos. Estes têm seus próprios espaços formais e os seus estabelecimentos: lojas de kebab, padarias, mercearias, barbeiro e varejista. Os migrantes da Índia e do Paquistão também constituem um dos grupos mais visíveis no espaço municipal, principalmente devido à homogeneidade racial da população majoritária na Polônia.

O momento em que realizamos a presente pesquisa foi muito particular, foi quando o número de migrantes do sul da Ásia, principalmente da Índia, estava aumentando bastante rápido entre 2017 e 2018. Quando naqueles anos se chegava ao município em questão, era possível enxergar os indivíduos ou grupos de origem indiana (entre eles os sikhs), sobretudo os homens, que andavam pelas ruas, faziam as compras ou apenas passeavam. Naquela época, percebia-se inclusive longas filas de pessoas que esperavam uma refeição em frente ao templo sikh, durante as celebrações de domingo.

Andando pelas ruas deste município suburbano extremamente diverso em termos étnicos, pode-se notar facilmente as diversas lojas e estabelecimentos, cujos proprietários são os migrantes. Na área onde foi realizada esta pesquisa, notamos que as placas foram escritas principalmente em polonês e inglês, porém também incluem os elementos estrangeiros, como fontes, palavras, bandeiras e outros símbolos. Os estabelecimentos observados tinham nomes específicos, apontando para sua forma estrangeira e uma etnia determinada.

Os sinais eram bastante simples, porém destacavam-se pela forma com que sublinhavam o caráter étnico ou oriental do negócio,

${ }^{6}$ No original: "Written and oral manifestations of the multilingual potential of immigrants [...] are not taken into consideration or are intentionally ignored". 
sendo mostrado nas fontes utilizadas, na referência ao país de origem, nas listas de produtos "exóticos" ou na imagem geral do "Oriente". Ao referir-se ao termo "oriental", revela-se uma prática interessante de domesticar a diferença e, ao mesmo tempo, criála. Ao se autodeterminarem de "orientais", os donos de restaurantes e lojas se referem à imagem estereotipada da Ásia e do Oriente Médio: uma imagem de paraíso, baseada em cores, conceitos de autenticidade e naturalidade. Por outro lado, o mesmo termo "oriental" cria distância e estabelece fronteiras - eles e nós, eu e o Outro.

Convém observar que a referência ao "Oriente" varia, dependendo da percepção coletiva acerca dos grupos determinados no país de origem, ou seja, a sua presença longa ou curta na Polônia, a visibilidade ou a invisibilidade no espaço público ou a presença estabelecida na cultura popular polonesa. Se olharmos para os restaurantes vietnamitas, podemos encontrar uma referência clara à "cozinha oriental" ou ao "gosto especial da Ásia" (Imagem 17), uma versão caseira do "Oriente", tanto na decoração dos bares quanto na comida que eles servem, sendo essa adaptada aos gostos e hábitos alimentares poloneses. Nota-se que os donos desses lugares servem pratos que não são caros, mas que aparentam ser elegantes e extraordinários. As lojas indianas, por sua vez, são relativamente caras e atendem, sobretudo, os clientes da Índia e de outros países asiáticos, bem como os poloneses interessados na cultura indiana ou na cozinha oriental. Observa-se que estes migrantes divulgaram seus negócios como Desi Bazaar. Kolorowy smak Indii (Bazar Desi. O sabor colorido da Índia), Little India, Asian \& Polski Sklep (loja asiática e polonesa) e Sklep Indyjski India Foods (Indian Shop India Foods). Nas placas, lemos os produtos vendidos na loja, que são propriamente discriminados, indicando ainda quais deles são autênticos, vindos “diretamente” da Índia, isto é, masalas, especiarias e arroz basmati (Imagem 2).

Outros restaurantes evidentemente "orientais", que são administrados por imigrantes, são os bares de kebab. Estes servem uma refeição rápida e atendem às classes média e baixa. Os bares de kebab também atraem os homens jovens, devido a um conceito da masculinidade fortemente ligado à comida, sobretudo à carne (ENGESET-POGRANICZNA, 2018). Os estabelecimentos de kebab também pertencem a migrantes de diferentes origens, por exemplo, Bengali, turco, egípcio ou libanês, sendo todos conhecidos como "turcos" por causa do estereótipo positivo dos turcos, em oposição aos árabes (BUCHOWSKI, 2016). A conexão com o Oriente Médio é visível nas decorações de interiores (mosaicos, fotografias, utensílios de mesa em exibição) e, às vezes, tal ligação pode ser encontrada nos nomes dos restaurantes.

Visto que muitos migrantes do sul da Ásia ou de outras regiões não falam polonês, um problema que eles têm que enfrentar constantemente é o da exclusão linguística no mercado de trabalho. É por isso que eles, assim como os outros grupos de migrantes, se envolvem em práticas econômicas informais e atuam no setor informal. Convém notar também a maneira como são divulgadas as informações sobre os empregos ou outros trabalhos remunerados informais entre os indivíduos excluídos da comunicação em língua polonesa. Assim sendo, entre os indianos, as informações são passadas no templo sikh, bem como nas lojas de comida indiana. Entre os grupos menores, privados de uma representação das instituições formais, as informações também podem circular via redes de migrantes e, às vezes, de um país para outro (por meio de ligações diaspóricas e pela mídia).

Os salões de beleza constituem outro nicho étnico que integra esta investigação. O "barbeiro turco" está localizado na rua principal do município e o seu serviço é divulgado em três idiomas (polonês, inglês e turco) (Imagem 3). Em uma entrevista com uma mulher ucraniana que trabalha lá como cabeleireira, descobrimos que ela é especializada em corte feminino e seus clientes são tanto poloneses como estrangeiros. Os homens que chegam ao estabelecimento também têm várias origens étnicas e são atendidos por um funcionário turco especializado em cortar e aparar a barba dos homens. É possível encontrar também os salões de beleza informais, como aquele anunciado por meio de um pôster manuscrito e de uma fotocópia divulgados em inglês, chamado $B K$ Indian Beauty Parlour (Imagem 4). O anúncio indica os serviços oferecidos, o horário de funcionamento (aberto todos os dias das 10 às 17 horas), o número de telefone e a localização (a mesma rua onde está localizado o templo sikh). Além disso, informa que o salão trabalha também aos domingos, dia em que a comunidade indiana se reúne no templo localizado na sua vizinhança.

Um novo fenômeno é uma maior cooperação entre vários grupos: nomeadamente, os homens e as mulheres ucranianos costumam trabalhar como vendedores, empregados de mesa ou outros funcionários "da linha de frente" nos estabelecimentos comerciais, cujos proprietários são outros migrantes menos fluentes em polonês. Um exemplo disso, conforme observado, foi o da

${ }^{7}$ As imagens estão no anexo deste texto. 
ucraniana que trabalhava no barbeiro turco como cabeleireira. Observamos que, quando estes grupos de migrantes trabalham em outras empresas étnicas, servem de intermediários entre os proprietários estrangeiros e os clientes poloneses. Embora a maioria dos ucranianos fale polonês, eles ainda são considerados estrangeiros pelo seu sotaque - chamado "oriental" - e muitas vezes discriminados por causa disso. Por outro lado, são vistos, cada vez com mais frequência, como mais "familiares" do que os outros estrangeiros.

Se olharmos para a sinalização pública e privada nas ruas do município, os ucranianos estão, na maior parte, escondidos em termos linguísticos. A única exceção são os anúncios bottom-up para os empregos divulgados em postes de sinalização e em quadros de avisos e anúncios de serviços de transferência de dinheiro ou serviços móveis, às vezes escritos em ucraniano ou em russo (foto 5). No entanto, o ucraniano e o russo estão presentes auditivamente na paisagem sonora da cidade: as duas línguas podem ser ouvidas no transporte público, nos locais de trabalho ou nas ruas.

Portanto, podemos afirmar que os sinais no espaço público não necessariamente refletem sempre a presença de falantes de um idioma. Se assim fosse, reconheceríamos que praticamente não há ucranianos em Raszyn ou, em geral, na Polônia. Enquanto isso, conforme mencionado, eles constituem o maior grupo de migrantes. Vale perguntarmo-nos se tal atitude significa que o conceito da paisagem socio-linguística não é útil. Acreditamos que não. Na próxima seção do presente artigo, analisaremos um outro exemplo, do sul do Brasil, o qual constitui o tema das nossas pesquisas realizadas na comunidade dos brasileiros de origem polonesa.

\section{CASO 2: RIO CLARO DO SUL, BRASIL}

presente investigação aborda o tema acerca dos descendentes de maior onda de migração dos poloneses que é datada dos anos de 1890-1891, e na literatura é denominada como a "febre brasileira". Os poloneses colonizaram três estados do sul do país, isto é, Paraná, Santa Catarina e Rio Grande do Sul, porém, é no Paraná onde moram mais descendentes dos poloneses. A emigração ou colonização da Polônia para o Brasil está relacionada com as mudanças econômicas e políticas, tanto na Europa como nas Américas ocorridas na segunda metade do século XIX. A partir dos meados da década de oitenta do século XIX, até aos meados da década de noventa, havia uma crise agrária (chamada da crise dos grãos), em consequência dos grãos mais baratos vindos dos Estados Unidos e do Canadá, que inundaram os mercados da Europa Ocidental. Escreve o historiador polonês Adam Walaszek: "Nas últimas décadas do século XIX cerca de dois terços da população rural oriunda das terras sob ocupação austríaca e prussiana, bem como um terço daquelas sob ocupação russa foram forçados a procurarem as atividades fora da sua própria aldeia” (WALASZEK, 2001, p. 13, tradução minha) ${ }^{8}$. Ao mesmo tempo, as pessoas começaram a migrar de uma forma maciça com fim de trabalharem na agricultura (Dinamarca, Alemanha, Áustria) e na indústria (Alemanha, Áustria, Estados Unidos, Canadá) ou com objetivo de se fixarem no território de outro país (Argentina, Brasil) (WALASZEK, 2001, p. 13). Consequentemente, houve uma queda dos preços dos grãos na Europa. No Brasil, por sua vez, após a abolição, havia uma necessidade urgente de contratar mãode-obra para trabalhar nas plantações de café e também na agricultura, lembrando que, naquela época, este país passava pelo processo de modernização. O governo do Brasil, para acalmar os plantadores de café que mais sofreram nesta crise, assinou um contrato com três empresas privadas, as quais deviam trazer cinquenta mil pessoas da Europa. Além disso, acreditava-se que os imigrantes poderiam "branquear" a população brasileira. Nota-se que, em 1890, a cada quatorze milhões de pessoas, cerca de dois milhões eram negras (MAZUREK, 2006, p. 33-34). Os camponeses poloneses vinham para o Brasil junto com os emigrantes da Alemanha e da Itália, e se dirigiam para o sul, onde recebiam a terra e arranjavam trabalho como agricultores. Estima-se que, na virada dos anos 80 e 90 do século XIX, desembarcaram no Brasil entre quarenta e oitenta pessoas do Reino da Polônia.

Atualmente, estamos realizando as pesquisas etnográficas e sociolinguísticas no estado do Paraná, sobretudo no município do Rio Claro do Sul (BIELENIN-LENCZOWSKA, 2018). Convém explicar que se trata de uma grande aldeia com algumas colônias, que é habitada, em grande maioria, por descendentes de poloneses e - em parte menor - por ucranianos. Os poloneses que vieram

\footnotetext{
${ }^{8}$ No original: "W ostatnich dekadach XIX wieku około dwóch trzecich ludności wiejskiej zaborów austriackiego i pruskiego, a także jedna trzecia zaboru rosyjskiego zmuszone było poszukiwać zajęcia poza własną wsią."
} 
para Rio Claro nos finais do século XIX (1890 e depois em 1896), em grande parte eram camponeses analfabetos oriundos de várias aldeias do Congresso da Polônia e, posteriormente, da ocupação austríaca (DEINA, 1990). Em apenas poucas casas, encontramos alguma documentação daquela época, por exemplo, os livros de oração, as fotografias ou as imagens sagradas. A maioria dos habitantes não tem nenhum conhecimento sobre as origens dos seus ancestrais - sabem apenas que estes vinham da Polônia, mas na documentação oficial figuravam como os cidadãos da Áustria ou Rússia.A região de Rio Claro ainda continua como uma aldeia agrícola, que integra a aldeia central de Rio Claro e cinco colônias, numeradas de 1 a 5. Na colônia n. 5 vivem principalmente os descendentes de ucranianos, enquanto nas outras, os de poloneses. A própria vila de Rio Claro é etnicamente mista, porém, notamos aqui uma maioria significativa de descendentes poloneses. Há uma estrada de terra que leva às colônias, contudo a viagem de carro de Mallet demora uma hora, apesar de estar localizada a menos de trinta quilômetros. As casas ficam a uma distância considerável da estrada e, se você quiser entrar em uma delas, deve ficar em frente ao portão e bater palmas forte. Ao ouvir este sinal, os anfitriões saem de casa e os convidam para entrar. Convém acrescentar que eles se cumprimentam em polonês: "dzień dobry" (bom dia), pela manhã; e "dobry wieczór" (boa noite), à tarde.

Ao olharmos para a paisagem cultural e sonora de Rio Claro, podemos logo perceber que esta região foi fortemente transformada pelos seus habitantes. Os migrantes que vieram para o sul do Brasil e que levaram consigo as suas famílias, colonizaram estas regiões e desenvolveram a agricultura. Cada família recebeu ou comprou um lote de terra (dez alqueires, ou seja, 25 ha), que cultivaram para seus próprios fins. Não há dúvida de que o grande desafio era, conforme mencionam os descendentes de imigrantes e tal como lemos nos registros das fontes, a terra teve que ser bem preparada para o cultivo, mas os colonos não tinham as ferramentas nem possuíam as habilidades para trabalhar em um ambiente novo e em um clima tão diferente. Muitos deles trouxeram consigo sementes de plantas e tentaram revitalizar as plantações da mesma forma como o faziam no seu país de origem, isto é, plantar trigo, centeio, lúpulo, beterraba ou batata. É claro que hoje em dia as mudanças globais afetam principalmente a agricultura - as monoculturas de soja e tabaco estão cada vez mais dominando este setor no Brasil. Contudo, até aos dias de hoje, mantêm-se muitos hábitos alimentares da área de origem, tal como os pierogi - prato bem comum em toda a região do Paraná -, a cerveja caseira ou a barszcz/borszcz (sopa de beterraba) (BIELENIN-LENCZOWSKA, 2018).

Os sinais da presença de imigrantes da Europa Oriental e Central também são visíveis na arquitetura local, nas decorações da casa ou na presença da imagem de Nossa Senhora de Częstochowa em casas, capelas e igrejas locais. As casas em Rio Claro são baixas, apenas de um andar, feitas principalmente de madeira e são bastante coloridas - geralmente azuis ou verdes. Os telhados íngremes e inclinados refletem a herança de seus antepassados que os construíram para proteger-se da neve (Imagem 7).

No entanto, a língua polonesa (ou ucraniana) praticamente não se nota na paisagem linguística, embora seja facilmente audível na paisagem sonora. Notamos os traços da presença de descendentes poloneses nos nomes das ruas que têm nomes poloneses (Imagem 8) ou nos nomes de lojas ou outros serviços pertencentes a descendentes poloneses. Percebemos tal situação em Mallet, onde há uma loja, que se chama Sklep - a palavra polonesa sklep significa loja (foto. 9). Além disso, os nomes poloneses também estão presentes nos cemitérios - lá se pode encontrar as placas escritas em polonês, principalmente aquelas datadas do ano anterior de 1938, mas não só. Algumas dessas placas provam os contatos que surgiram entre o idioma polonês e o português, por exemplo Tęsknota rodziny - esta é uma tradução literal das "saudades da família”. Curiosamente, em polonês, não escrevemos e não falamos desta maneira (Imagem 10).

A maioria dos habitantes de Rio Claro, e sobretudo da colônia, fala polonês. Porém, trata-se de conhecimento de um código falado, isto é, de um dialeto derivado de lugares de origem de onde vinham os seus antepassados. Quanto à língua escrita, os moradores de Rio Claro dominam principalmente a língua portuguesa, ou seja, o português é o único código escrito para a grande maioria desses habitantes. Mesmo aqueles que falam muito bem polonês contemporâneo, porque, por exemplo, estavam na Polônia ou participaram de vários cursos, na comunicação escrita, em geral, preferem a língua portuguesa. Acredita-se que o idioma polonês escrito não foi passado para as posteriores gerações de descendentes por duas razões: porque muitos deles eram analfabetos; e também porque, por mais de um meio século, o ensino de polonês foi proibido.

Ao mesmo tempo, a língua é extremamente importante para os brasileiros de descendência polonesa e, curiosamente, ainda existem muitas ideologias em torno da língua polonesa. Segundo Kathryn Woolard, "[...] as ideologias da linguagem não se 
referem apenas à linguagem. Em vez disso, estas visualizam e promovem os laços da linguagem com a identidade, a estética, a moralidade e a epistemologia" (WOOLARD, 1998, p. 3, tradução minha) ${ }^{9}$. Portanto, essas ideologias mostram a beleza da língua polonesa, reconhece o seu essencial para a questão da identidade e revela a superioridade de seus usuários em relação com os outros. Vale a pena refletir o caso de um dos meus interlocutores que afirma que: "O polonês que não fala polonês, é um polonês estúpido", mostrando assim a importância de transmissão da língua como um elemento essencial da identidade. A outra interlocutora compara as palavras em português e polonês, acreditando que em polonês as palavras soam mais lindo: "Olha que lindo: mamusia, tatuś. E não mamai, papai".

Convém explicar que essas ideologias não são recentes. Nos documentos escritos datados do início do século XX, encontramos muitas informações sobre a necessidade do ensino e da transmissão da língua polonesa. No Jornal Polonês no Brasil (Gazeta Polska w Brazylii, 1932/3) lemos que: "A língua polonesa falada corretamente não é inferior a outra língua qualquer do mundo. Enquanto à riqueza de formas, supera todas as línguas do mundo, é mais flexível do que latim e grego [...]. Em nossa língua, é mais fácil expressar os sentimentos humanos mais elevados e sofisticados" (BIELENIN-LENCZOWSKA; STĄPOR, 2017, p. 45); ou (no mesmo jornal, 1924/21): "Desgraça aquele, que põe na fala polonesa as palavras estrangeiras ou emprestadas da língua estrangeira, porque isso a suja" (BIELENIN-LENCZOWSKA, STĄPOR, 2017, p. 47).

Atualmente, a língua polonesa é cultivada basicamente apenas pelas pessoas adultas ou idosas. Há pouca gente jovem, e muito menos crianças, que se comunicam em polonês à vontade. Tal fato é devido a várias coisas: à falta de possibilidade de ensino da língua polonesa, a uma alta taxa da mobilidade das pessoas e à ignorância do código escrito. Em consequência da promulgação, em 1938, da lei de Getúlio Vargas, a qual proibiu o uso de línguas étnicas, logo foram fechadas as escolas que ensinavam outras línguas que não fossem o português (GOCZYŁA FERREIRA, 2019). O polonês permaneceu em uso dentro de casa, mas basicamente era apenas falado. Nas biografias linguísticas dos interlocutores em Rio Claro, é muito comum lembrar que quando, na idade de 6-7 anos, eles começavam o ensino fundamental, ainda não falavam português. Portanto, eles ainda lembram muito bem dos primeiros desafios enfrentados na escola, por exemplo: "Eu não sabia falar nada brasileiro, e o professor não sabia falar polonês. As irmãs [freiras] me ensinaram um pouco a ler em polonês, mas no começo era muito difícil, muito difícil” - disse um interlocutor de 47 anos. Para os idosos, por sua vez, a principal língua falada até hoje continua sendo o polonês. Nas narrativas, encontramos as lembranças das pessoas cujos pais, avós ou sogros não aprenderam português ao longo de sua vida. Por outro lado, encontramos uma brasileira que não tinha origem polonesa, mas aprendeu o idioma para poder comunicar-se com a sua sogra. Nos dias de hoje, os jovens têm mais acesso à educação, são mais familiarizados com a língua escrita e a língua das mídias o português - embora muitos deles também se lembrem da infância, quando a língua polonesa era falada em casa. Agora essas pessoas não conseguem dizer em polonês tudo o que querem, porque não conhecem a sua variedade contemporânea e, em muitos dos casos, não conhecem ninguém com quem poderiam se comunicar em polonês todos os dias. Portanto, na prática, a principal língua que mais usam os meus interlocutores é o código misto (cf. BLOMMAERT, 2013), que contém os elementos de dialeto polonês/ dialetos poloneses e da língua coloquial portuguesa. Convém explicar que falamos de um dialeto do polonês formado ao longo de 130-140 anos de convivência em uma diáspora. É um dialeto de origem da colônia, que foi falado por um determinado grupo social, nomeadamente pelos camponeses, e foi criado e desenvolvido em confronto com o português e outras línguas locais. Porém, quando se fala do patrimônio cultural da diáspora polonesa, é importante levar em consideração a literatura e os outros textos escritos como, por exemplo, os jornais, lembrando que é o idioma falado por um grupo determinado, sobretudo, os intelectualistas que representavam a classe urbana. A fala local da colônia, ainda que com maior vitalidade do que a língua nas cidades, permanece escondida. Da mesma forma, quando se introduz o idioma polonês nos programas das escolas ou quando se ministra as aulas em várias associações, os palestrantes vêm geralmente da Polônia e, portanto, não conhecem o dialeto local. Não há dúvidas de que o idioma polonês é ensinado na sua forma padronizada e contemporânea, mas em muitas situações continua incompreensível e, inclusive, parece estranho. Junto com a ideologia que o padrão e uma forma "neutra", sem sotaque e sem variações locais ou sociais, e com a norma monolíngue (GOGOLIN; SIEMUND; SCHULZ; DAVYDOVA, 2013) no Brasil, os falantes julgam que o dialeto local falado por eles é pior do que o padrão: nieakuratny [incoretto], misturado. Talvez bastaria ministrar algumas aulas sobre os dialetos locais na Polônia e mostrar que, hoje em dia, as pessoas também falam de maneiras

\footnotetext{
${ }^{9}$ No original: "Ideologies of Language are not about language alone. Rather, they envision and enact ties of language to identity, to aesthetics, to morality, and to epistemology."
} 
diferentes e tal prática não deveria causar nenhuma vergonha, nem levar à discriminação.

\section{CONSIDERAÇÕES FINAIS}

A questão que surge na presente pesquisa realizada na Polônia, mas também no Brasil, é que a quantidade de comunicação formal (top-down) com um determinado grupo ou em um determinado idioma, não necessariamente diz tudo sobre o envolvimento deste grupo no mercado de trabalho ou sobre a vida social dentro de um ambiente. A falta de sinais em uma determinada língua não é um sintoma da ausência dos falantes desta língua no espaço público. Tanto os ucranianos na Polônia, como os descendentes dos poloneses no sul do Brasil formam os grupos relativamente grandes e importantes nos espaços onde moram e trabalham.

O conceito que pode ajudar a entender o funcionamento de diferentes grupos em Raszyn e dos descendentes dos poloneses em Rio Claro do Sul é o conceito de "diversidade escondida", proposto pelas sociolinguistas russas Vlada Baranova e Kapitolina Fedorova (2018), que realizaram uma pesquisa no âmbito da paisagem linguística de São Petersburgo. As acadêmicas discutiram que os sinais da presença de migrantes e de minorias naquela cidade está escondida. Aliás, argumentam que a análise da paisagem linguística revela as relações de poder entre diferentes grupos étnicos no espaço público urbano:

É importante ressaltar que existe uma disparidade muito forte entre os espaços abertos, públicos e fechados, em termos de uso da linguagem. Os idiomas dos migrantes podem ser usados dentro destes cafés, mas não fora: na superfície, as informações são divulgadas em russo [o idioma dominante], mas quando os clientes entram, podem ser servidos em outros idiomas e, em alguns casos, aquele outro idioma pode inclusive dominar. (BARANOVA; FEDOROVA, 2019, p. 23, tradução minha) $)^{10}$

Tais relações de poder, entre o idioma dominante e os idiomas migrantes, também estavam presentes nos campos de pesquisa, com alguns idiomas quase inexistentes ou invisíveis. Por exemplo, em Raszyn, existem dois restaurantes vietnamitas, que atendem tanto os clientes poloneses, como o próprio grupo étnico. Embora o cardápio seja escrito em polonês, às vezes, aparecem umas palavras escritas com erros. O espaço aberto disponível para os clientes aparentemente segue as regras polonesas, enquanto o espaço acessível somente para os seus funcionários (cozinha, depósitos etc.), segue as regras vietnamitas. Todo o espaço é organizado de tal maneira que incorpora a imagem do Oriente com os elementos facilmente identificáveis como asiáticos, vietnamitas ou "exóticos" (por exemplo, grandes leques vietnamitas, flores exóticas, fotografias nas paredes que mostram as paisagens do Vietnã). Em muitos restaurantes vietnamitas na Polônia, a televisão e a música vietnamitas são sinais audíveis de alteridade e aumentam a sensação de estar em um lugar "exótico"; esse também é o caso no município em questão.

Um dos restaurantes analisados na presente pesquisa, o Daystar Restauracja. Kuchnia Orientalna (Restaurante Daystar. Cozinha Oriental), possui um espaço interno para os clientes vietnamitas que desejam organizar festas. As faixas formam uma espécie de cerca ao redor do pátio, criando desta forma um espaço interno, mais íntimo e menos visível para os outros (Imagem 11).

Em Rio Claro do Sul praticamente não encontramos nenhum sinal de polonês, mas durante os eventos diaspóricos, podemos encontrar as placas escritas em polonês. Estas geralmente são colocadas ao lado das placas escritas em português e se referem, por exemplo, aos votos de boa festa (Imagem 12). Os nomes dos pratos também são escritos em polonês, às vezes com alguns erros ou adaptados para a pronúncia portuguesa, por exemplo. Pierogi/pierogue/pierogui ou gołąbi escrito como golompki ou golombki (Imagem 13).

Assim sendo, podemos argumentar que a invisibilidade de determinados idiomas não necessariamente significa a falta de seus usuários no espaço da cidade. Convém lembrar que pode significar a falta de prestígio de um determinado idioma ou a sua ausência na comunicação escrita. Além disso, alguns idiomas, assim como seus usuários, permanecem invisíveis.

\footnotetext{
${ }^{10}$ No original: "Importantly, there is very strong disparity between open, public, and closed, inner spaces in term of language use. Migrants' languages can be used inside these cafés, but not outside: on the surface they are advertised through Russian but when customers get inside they can be served in other language, and in some cases this other language can even dominate Russian."
} 
Seguindo os estudiosos que combinam os métodos etnográficos com a linguística, aproveitamos a oportunidade para destacar a presença de idiomas no espaço público em relação à (in)visibilidade de seus usuários. Por conseguinte, argumentamos que as práticas linguísticas são as práticas sociais e culturais, enquanto a paisagem reflete a vida social e cultural das pessoas. Portanto, o conceito de paisagem linguística, focado exclusivamente na comunicação escrita, é muito estreito. Portanto, o conceito de paisagem sócio-linguística inclui também as linguagens que não são escritas. Conforme mostrado ao longo desta pesquisa, percebemos que existem vários grupos quase invisíveis em termos linguísticos nos sinais escritos, mas por outro lado mantêm uma forte presença audível nos lugares em que habitam.

\section{REFERÊNCIAS}

BARANOVA, V.; FEDOROVA, K. Invisible minorities" and "hidden diversity" in Saint-Petersburg's linguistic landscape. Language and Communication, n. 68 p.17-27, 2019.

BEN-RAFAEL, E.; SHOHAMY,E.; AMARA, M. H.; TRUMPER-HECHT, N. Linguistic landscape as symbolic construction of the public space: the case of Israel. International Journal of Multilingualism, v.3. n. 1, p. 7-30, 2006.

BIELENIN-LENCZOWSKA, K.; STĄPOR I. Língua como patrimônio cultural. Práticas linguísticas dos descendentes dos poloneses no sul do Brasil. Revista del CESLA n. 20, p. 39-55, 2017.

BIELENIN-LENCZOWSKA, K. Pierogi z fiżonem. Praktyki jedzeniowe i tożsamość Brazylijczyków polskiego pochodzenia w południowobrazylijskiej wsi, Studia Migracyjne - Przegląd Polonijny, n.167, p. 23-47, 2018.

BLOMMAERT, J. The conservative turn in Linguistic Landscape Studies. 2016. Disponível em: http://alternative-democracyresearch.org/2016/01/05/the-conservative-turn-in-linguistic-landscape-studies. Acesso em: 11 abr. 2020.

BLOMMAERT, J. Ethnography, superdiversity and linguistic landscapes. Bristol, U.K.: Multilingual Matters, 2013.

BLOMMAERT, J.; MALY, I. Ethnographic linguistic landscape analysis and social change: A case study. Tilburg Papers in Culture Studies, n. 100, p. 1-27, 2014.

BRECKNER I.; PEUKERT H.; PINTO A. The delicate search for language in spaces. Multilingualism as a resource in urban development? In: SIEMUND P. et al. (org.) Multilingualism and Language Diversity in Urban Areas. Acquisition, identities, space, education. Amsterdam / Philadephia: John Benjamins Publishing Co., 2013. p. 210-226.

BUCHOWSKI, M. Making Anthropology matter in the heyday of islamophobia and the 'Refugee Crisis': the case of Poland. Český lid: etnologický časopis v. 103, n.1, p. 51-67, 2016.

DEINA M. . Colônia Rio Claro. Esta terra tem história. Curitiba: Gráfica Vicentina, 1990.

ENGESET-POGRANICZNA, M. 2018. Kebab nasz powszedni. Magazyn kontakt. available online: http://magazynkontakt.pl/kebab-nasz-powszedni.html.

GOCZYŁA FERreIRA, A. 2019. A presença da língua polonesa na Colonia Dom Pedro II, Campo Largo, Paraná. Dissertação (Mestrado em Letras) - Setor de Ciências Humanas da Universidade Federal do Paraná, Curitiba, 2019

GOGOLIN I., SIEMUND P., SCHUlZ M., DAVYDOVA J. 2013. Multilingualism, language contact, and urban areas. Multilingualism and Language Diversity in Urban Areas. In: SIEMUND P. et al. (org.) Multilingualism and Language Diversity in Urban Areas. Acquisition, identities, space, education. Amsterdam / Philadephia: John Benjamins Publishing Co., 2013, p. 1-15. 
HIRSCH E., O'HANLON M. (org.). Anthropology of landscape. Perspectives on place and space. Oxford: Oxford University Press, 1995.

JIA LOU, J. The linguistic landscape of Chinatown. A sociolinguistic ethnography. Bristol, Buffalo: Multilingual Matters, 2016.

JÓŹWIAK I., PIECHOWSKA M. 2017. Crisis-driven mobility between Ukraine and Poland. What does the available data (not) tell us. CMR Working Papers, n.99, p. 1-26, 2017.

KINDLER, M. A 'Risky' Business? Ukrainian migrant women in Warsaw's domestic work sector: Amsterdam: Amsterdam University Press, 2011.

LANDRY R.; BOURHIS, R. Y. Linguistic Landscape and Ethnolinguistic Vitality: An Empirical Study. Journal of Language and Social Psychology, v.16, n.1, p. 23-49, 1997.

NEKVAPIL, J. Language biographies and the analysis of language situations: on the life of the German community in the Czech Republic. International Journal of the Sociology of Language, n. 162, p. 63-83, 2003.

PIŁAT, A. Obcokrajowcy mieszkający w gminie Raszyn - wzory integracji i relacje ze społecznością lokalną. In: Mała Azja w Polsce. Plany i strategie imigrantów z Azji i Bliskiego Wschodu w Polsce. Warszawa: Instytut Spraw Publicznych, 2013.

SZYMAŃSKA-MATUSIEWICZ, G. Migration and cultural flows between Vietnam and Poland. Asian and Pacific Migration Journal, p. 1-21, 2016.

TRINCH, Sh.; SNAJDR, E. What the signs say: gentrification and the disappearance of capitalism without distinction in Brooklyn. Journal of Sociolinguistics, v.21, n.1, p. 64-89, 2017.

VERTOVEC, S. Super-diversity and its implications. Ethnic and Racial Studies, v.30, n.6, p. 1024-1054, 2007.

SAMUELS, D. W.; MEINTJES, L.; OCHOA, A.M.; PORCELLO, T. Soundscapes: toward a sounded anthropology. Annual Review of Anthropology, v. 39, p. 329-345, 2010.

WALASZEK A. (org.). Polska diaspora. Kraków: Wydawnictwo Literackie, 2001.

WOLDEMARIAM H., LANZA E. Imagined community. The linguistic landscape in a diaspora. Linguistic Landscape 1, n. 1-2, p. 172-190, 2015.

WOOLARD, K. Introduction: Language ideology as a field of inquiry. In: BAMBI, B. et al. (org.). Language ideologies: practice and theory. New York: Oxford University Press, 1998. p. 3-47.

\section{()(1) $\circledast$}


ANEXO A - IMAGENS DA PESQUISA

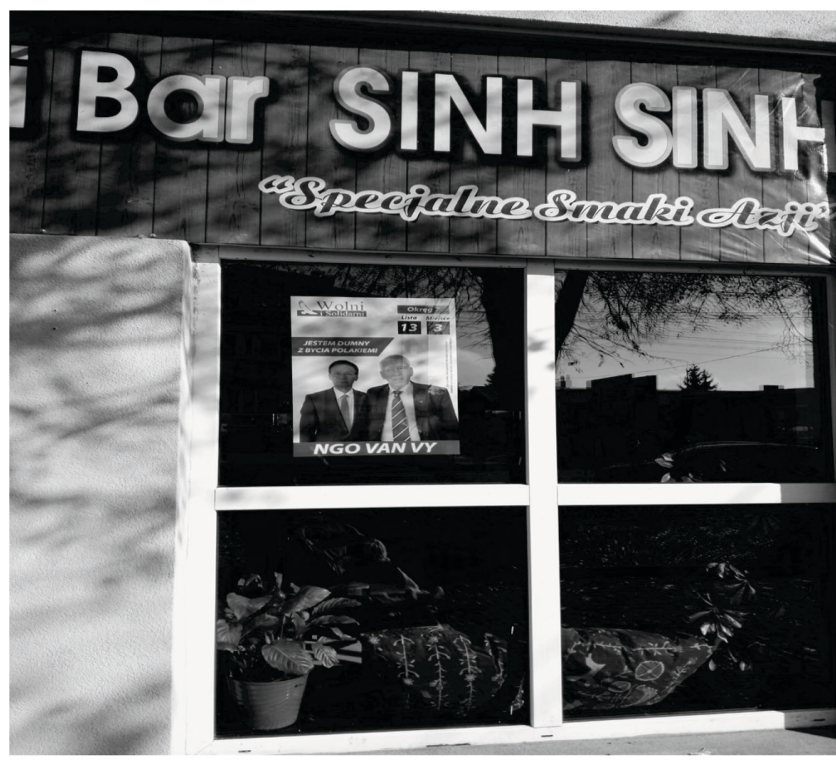

Imagem 1: Restaurante vietnamita Sinh Sinh, Raszyn Fonte: Patzer (2017)

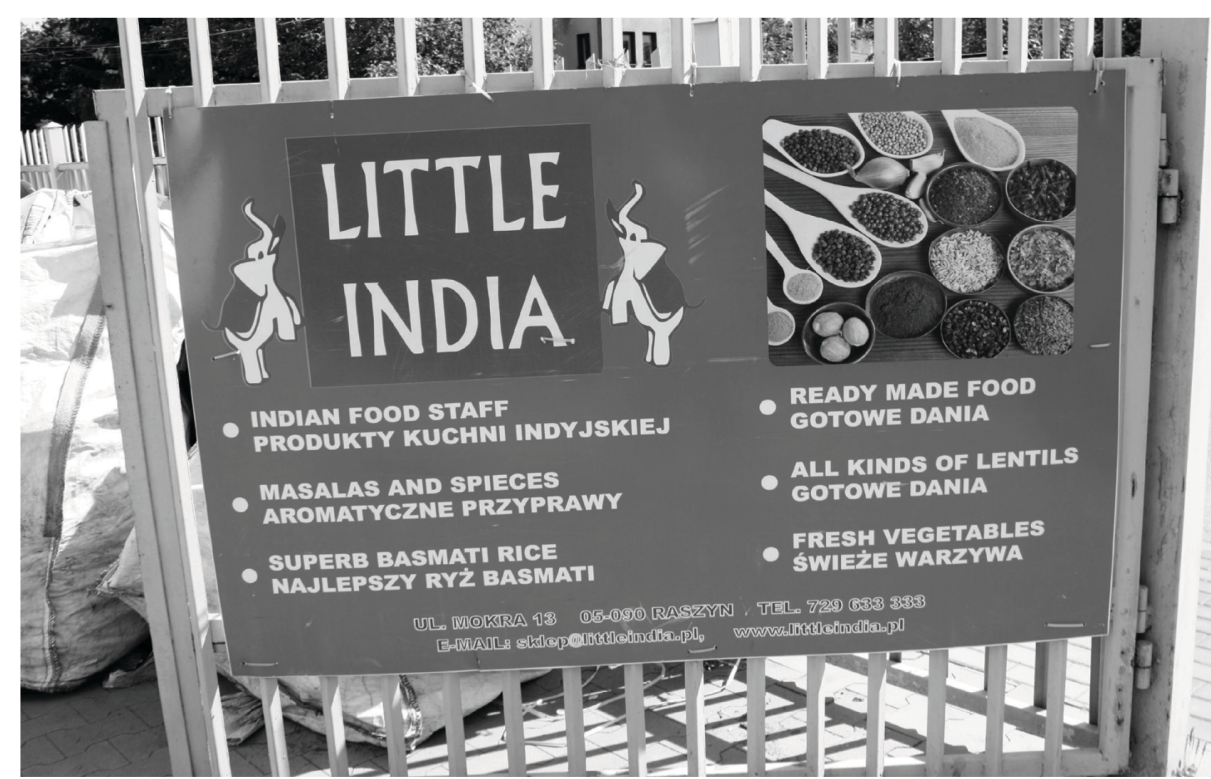

Imagem 2: Loja "Little India"

Fonte: Patzer (2017) 


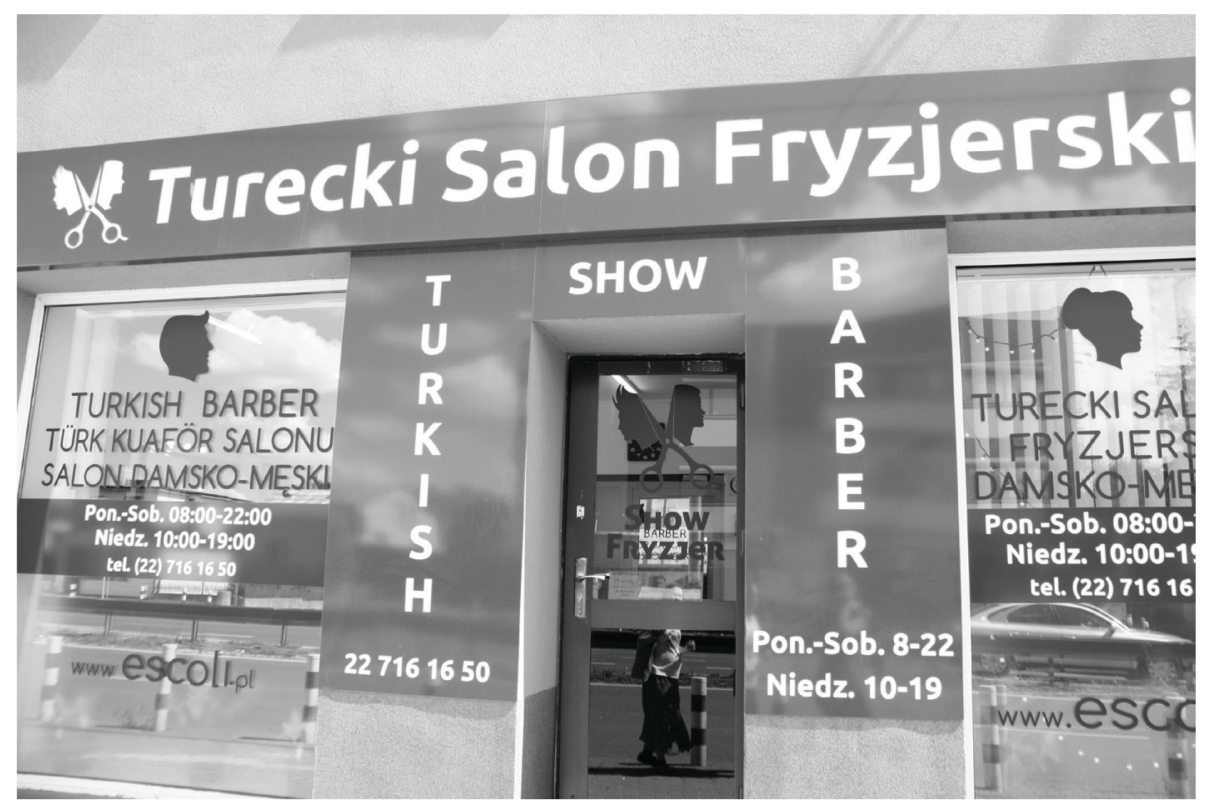

Imagem 3: Barbeiro turco, Raszyn

Fonte: Patzer (2017)

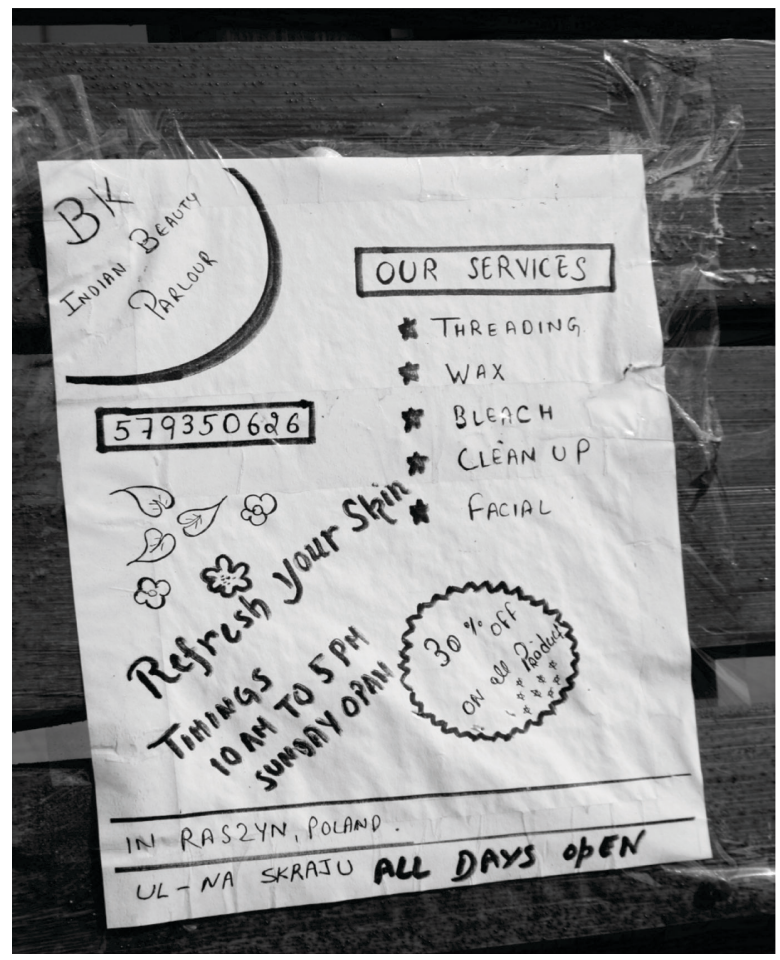

Imagem 4: Indian Beauty Parlour, Raszyn

Fonte: Patzer (2017) 


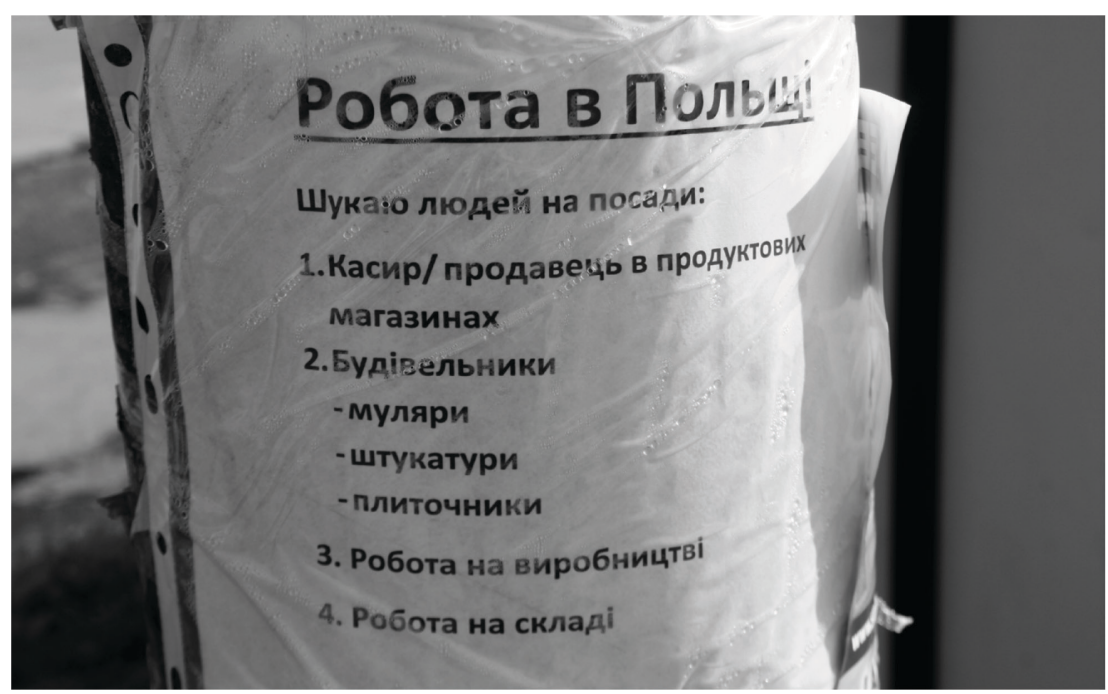

Imagem 5: Anuncio em ucraniano sobre as possibilidades de trabalho na Polonia, Raszyn Fonte: Patzer (2017)

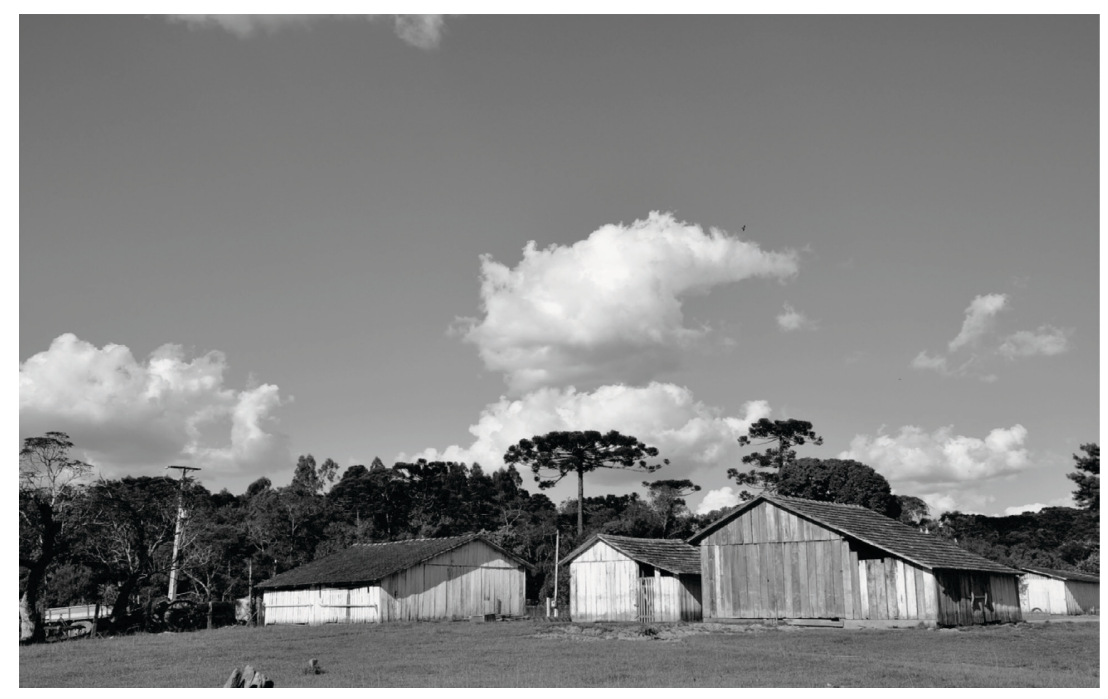

Imagem 6: Paisagem do Rio Claro do Sul Fonte: a autora (2015)

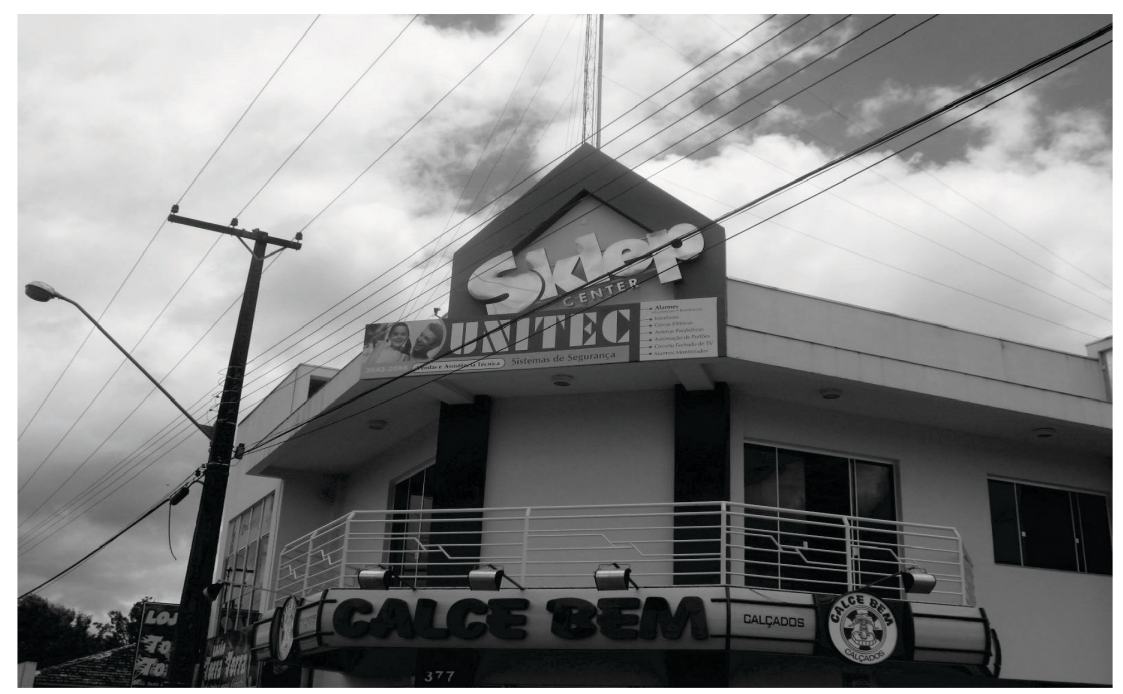

Imagem 7: Loja Sklep, Mallet 
Fonte: a autora (2015)

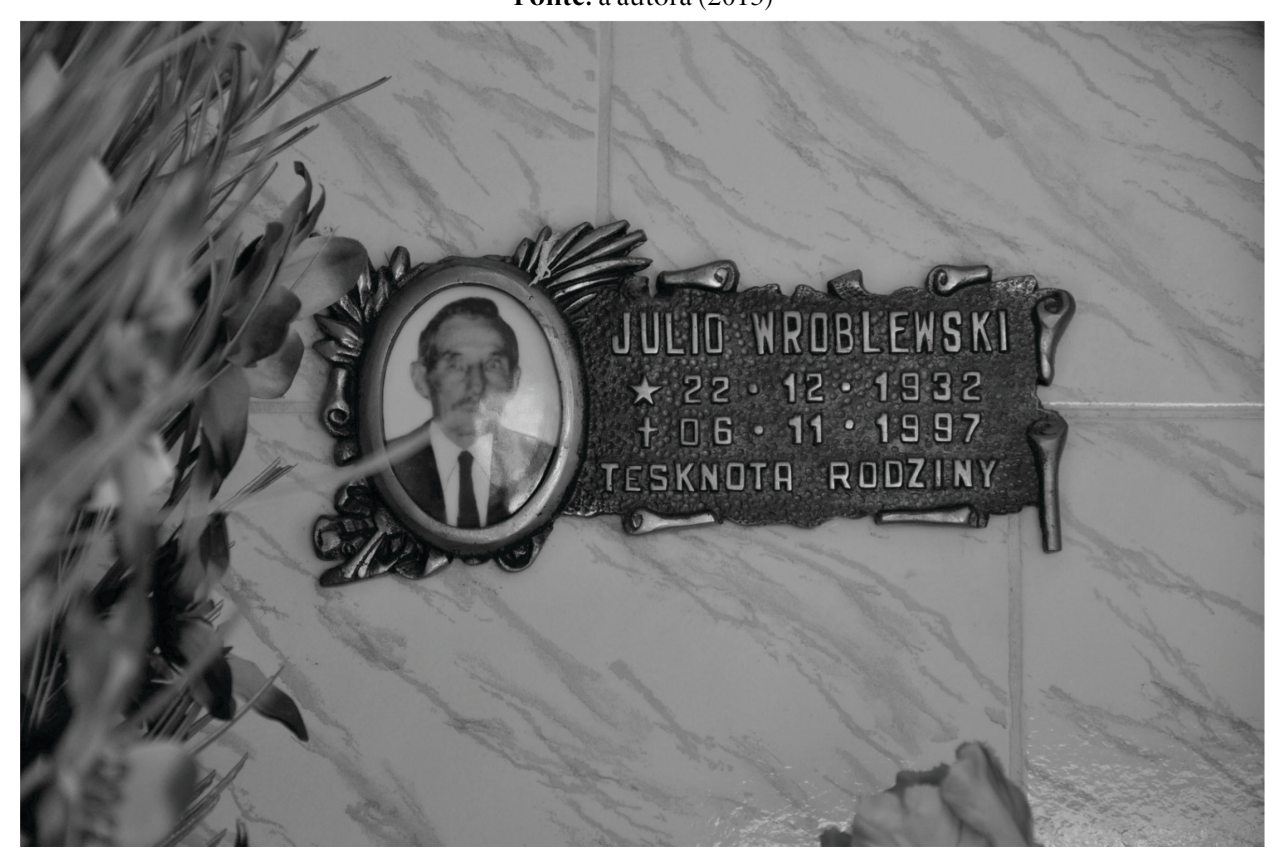

Imagem 8: Placa em cemitério - Rio Claro do Sul Fonte: a autora (2015)

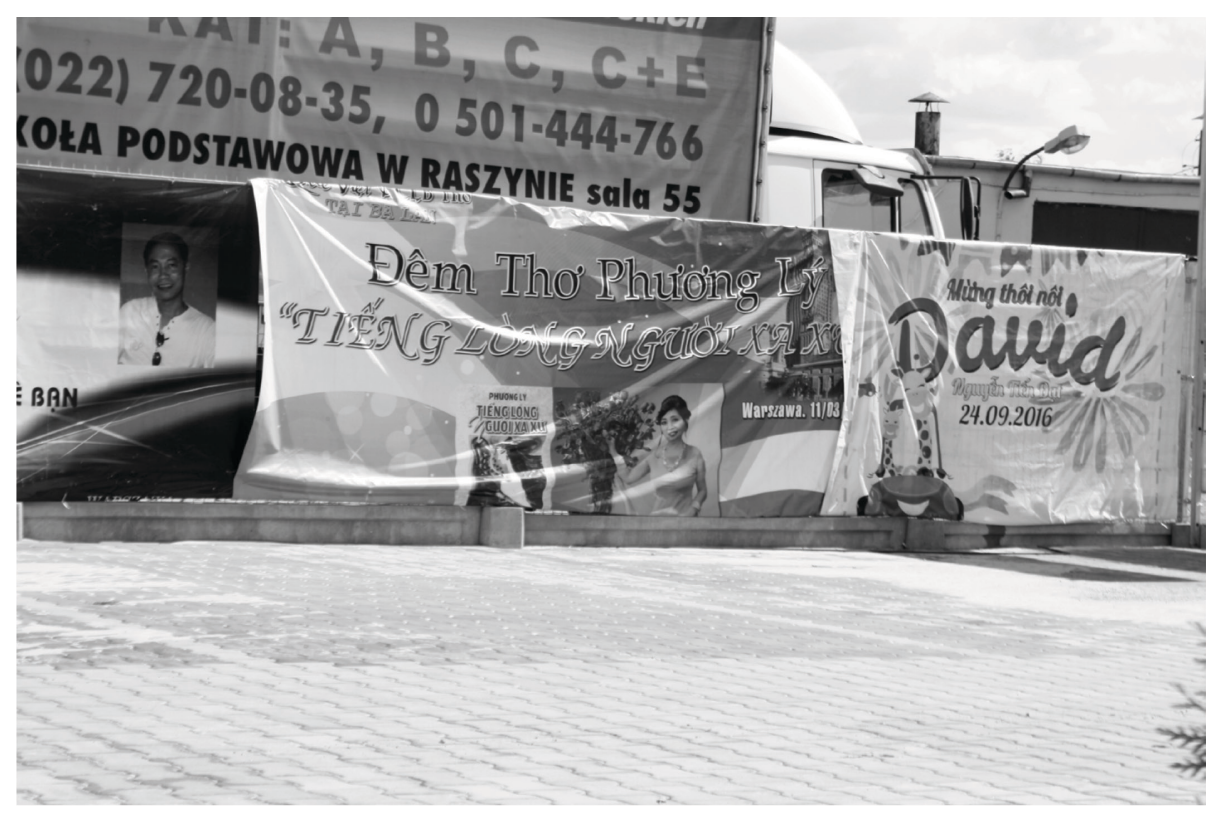

Imagem 9: Patio de restaurante Daystar, Raszyn

Fonte: Patzer (2017) 


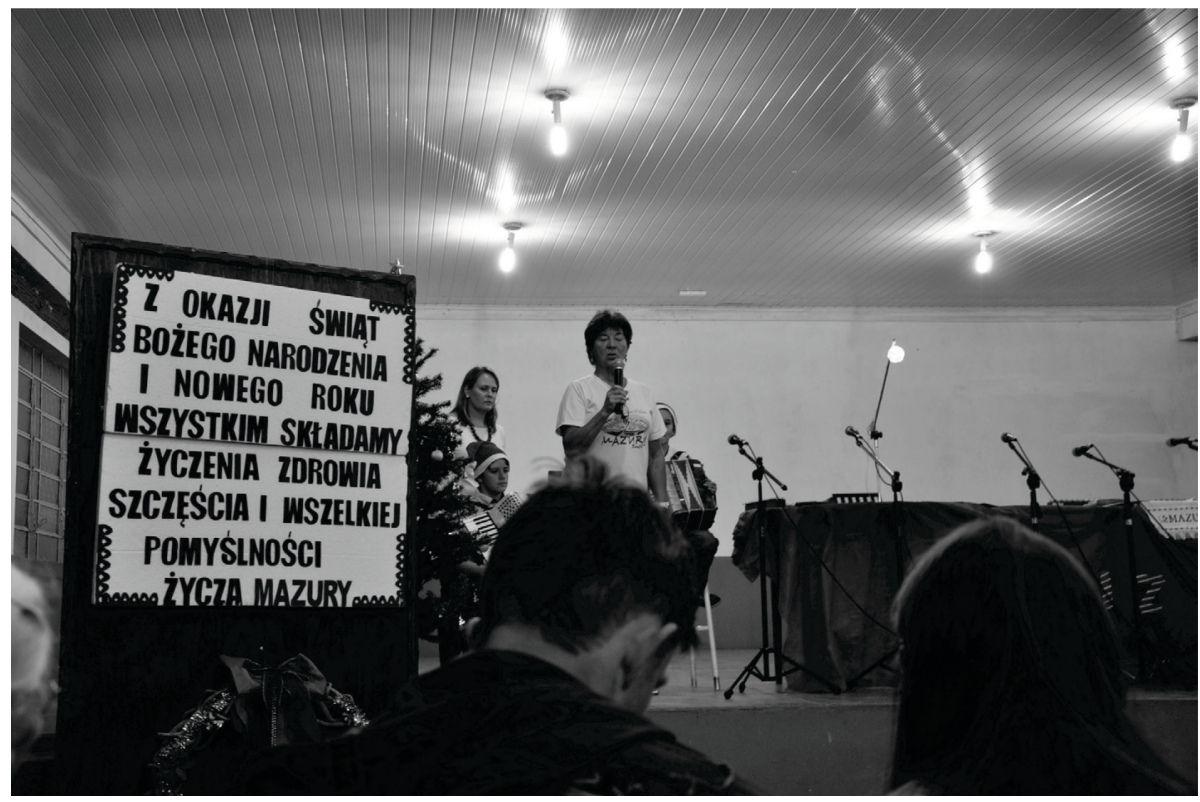

Imagem 10: Placa do grupo folklorico Mazury em Mallet

Fonte: a autora (2015)

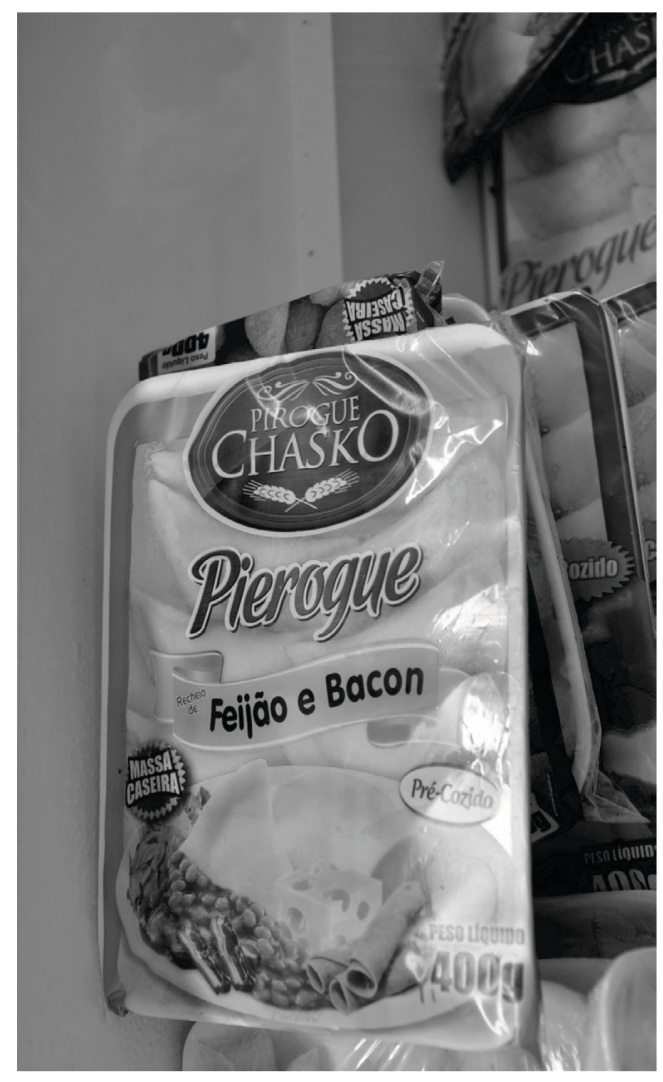

Imagem 11: Pierogue em supermercado em Mallet

Fonte: a autora (2015) 